\title{
Yield and Nutritional Quality of Water Spinach (Ipomoea aquatica) as Influenced by Hydroponic Nutrient Solutions with Different pH Adjustments
}

\author{
Lichun Wang ${ }^{1,2}$, Xiaoli Chen ${ }^{1,3}$, Wenzhong Guo ${ }^{1,2}$, Yinkun $\mathrm{Li}^{1,2}$, Hua Yan ${ }^{1,2}$ and Xuzhang Xue ${ }^{1,2^{*}}$ \\ ${ }^{1}$ Beijing Research Center for Information Technology in Agriculture, Beijing Academy of Agriculture and Forestry Sciences, \\ Beijing 100097, China \\ ${ }^{2}$ Beijing Agricultural IOT Engineering Technology Research Center, Beijing 100097, China \\ ${ }^{3}$ Key Laboratory of Urban Agriculture (North), Ministry of Agriculture, Beijing 100097, China \\ *For correspondence: xuexz@nercita.org.cn; wanglc@nercita.org.cn
}

\begin{abstract}
It is critical to identify effective buffer chemicals which are capable of regulating the $\mathrm{pH}$ of nutrient solution to a desirable level for best hydroponic production of crops. Greenhouse experiments were conducted to examine the $\mathrm{pH}$ dynamics of nutrient solutions amended with different inorganic acids during hydroponic production and the yield and nutritional quality of

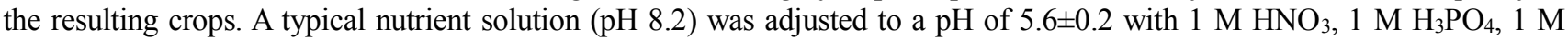
$\mathrm{H}_{2} \mathrm{SO}_{4}$, and a 3:1:1 (v/v/v) mixture of all three acids, respectively. Water spinach (Ipomoea aquatica Forsk) was hydroponically grown for $25 \mathrm{~d}$ in the unadjusted control and the $\mathrm{pH}$-adjusted nutrient solutions. The different treatments were monitored for $\mathrm{pH}$ changes of the nutrient solution, and measured for shoot yield and nutritional quality of the grown water spinach. It showed that the solution $\mathrm{pH}$ adjustments introduced additional anions but did not significantly increase the electrical conductivity (EC). The $\mathrm{HNO}_{3}-\mathrm{H}_{3} \mathrm{PO}_{4}-\mathrm{H}_{2} \mathrm{SO}_{4}$ mixture was able to achieve an optimal solution $\mathrm{pH}$ ranging from 5.5 to 6.5 , while any of the acids only failed to maintain the solution $\mathrm{pH}$ within optimal range for $48 \mathrm{~h}$ after each adjustment. The shoot fresh weight, dry weight, and height of water spinach grown in the mixed acids-treated solution were the greatest among the five treatments. Relative to the control, the acid mixture treatment also increased the vitamin $\mathrm{C}$, soluble sugar and crude protein contents in plants. Thus, the mixed 3:1:1 (v/v/v) $\mathrm{HNO}_{3}-\mathrm{H}_{3} \mathrm{PO}_{4}-\mathrm{H}_{2} \mathrm{SO}_{4}$ is recommended for regulating the $\mathrm{pH}$ of nutrient solution in hydroponic production of leafy greens. (C) 2017 Friends Science Publishers
\end{abstract}

Keywords: Hydroponics; pH; Acids; Nutrient solution; Water spinach

\section{Introduction}

Hydroponics, a method for growing crops in nutrient solutions instead of mineral soils, has been increasingly practiced in horticultural production due to its high water, nutrient, and labor efficiencies (Rius-Ruiz et al., 2014; Aftab et al., 2015). The chemical composition of hydroponic solution can be readily adjusted to meet the specific requirements of particular crops for nutrients (Caruso et al., 2011). Typically a nutrient solution contains all essential plant nutrients in water soluble forms and in appropriate concentrations. Nevertheless, the supply buffering capacity of a nutrient solution is nearly null (Gorbe, 2009), leading to high danger of hydroponic plants to nutrient deficiency and ion toxicity (Gorbe and Calatayud, 2010).

The $\mathrm{pH}$ of hydroponic solution is a major factor affecting nutrient availability and plant uptake (Spinu et al., 1997). The existing forms (speciation) and subsequently the phytoavailability of a nutrient element in the solution are greatly influenced by solution $\mathrm{pH}$. For example, increasing
$\mathrm{pH}$ to above 7.3 would change the predominant form of $\mathrm{P}$ in solution from $\mathrm{H}_{2} \mathrm{PO}_{4}^{-}$to $\mathrm{HPO}_{4}{ }^{2-}$. In an alkaline solution, $\mathrm{Ca}^{2+}, \mathrm{Mg}^{2+}, \mathrm{Fe}^{3+}, \mathrm{Cu}^{2+}$, and other polyvalent cations would form precipitates with $\mathrm{OH}^{-}$and $\mathrm{CO}_{3}{ }^{2-}$ and become unavailable to plants. In strongly acidic solutions, $\mathrm{H}^{+}$ competes with other mineral nutrients for plant absorption (Brady and Weil, 2007), to ensure the best availability of essential nutrients to hydroponic plants, the $\mathrm{pH}$ of a nutrient solution should be maintained in a narrow range usually between 5.5 and 6.5 (Webb, 1993). Nevertheless, the $\mathrm{pH}$ of a nutrient solution may change during hydroponic production owing to selective absorption of soluble ionic nutrients by plants (Kim et al., 2005). To absorb cation and anion nutrients, plant roots release $\mathrm{H}^{+}$and $\mathrm{HCO}_{3}^{-}$, respectively, into the solution for exchange, causing shifting of the solution $\mathrm{pH}$ over time (Brady and Weil, 2007).

The commonly used $\mathrm{pH}$ regulators are inorganic acids such as nitric acid (Wheeler et al., 1990; Webb, 1993; Savvas and Adamidis, 1999; Savvas et al., 2006), hydrochloric acid (Domingues et al., 2012), and sulfuric

To cite this paper: Wang, L., X. Chen, W. Guo, Y. Li, H. Yan and X. Xue, 2017. Yield and nutritional quality of water spinach (Ipomoea Aquatica) as influenced by hydroponic nutrient solutions with different pH adjustments. Int. J. Agric. Biol., 19: 635-642 
acid (Massa et al., 2011; Giuffrida and Leonardi, 2012). Addition of $\mathrm{HNO}_{3}$ provides extra $\mathrm{N}$ nutrient in the form of $\mathrm{NO}_{3}{ }^{-}$. Due to chloride ions are harmful to most crops (Bernstein, 1975), hydrochloric acid ( $\mathrm{HCl})$ cannot be used for hydroponic solution $\mathrm{pH}$ adjustment. Use of sulfuric acid $\left(\mathrm{H}_{2} \mathrm{SO} 4\right)$ and phosphoric acid $\left(\mathrm{H}_{3} \mathrm{PO}_{4}\right)$ for the purpose has been rarely reported. Little is known about the capability of these inorganic acids in maintaining a relatively stable $\mathrm{pH}$ of hydroponic solution and the effects of these acids as a $\mathrm{pH}$ adjustment on the yield and quality of hydroponic plants. Furthermore, when a single acid (e.g., $\mathrm{HNO}_{3}$ ) is used to regulate the solution $\mathrm{pH}$, the concentration of the acid radical anion (e.g., $\mathrm{NO}_{3}{ }^{-}$) in the nutrient solution will increase and become excessive for hydroponic plants (Prasad et al., 2001; Bugbee, 2004). This study aimed to identify a practical buffer agent capable of effectively regulating the $\mathrm{pH}$ level of hydroponic nutrient solution and promoting plant growth. To this end, we examined the $\mathrm{pH}$ dynamics of nutrient solutions amended with different inorganic acids during hydroponic production and the yield and nutritional quality of the crops.

\section{Materials and Methods}

\section{Preparation of Hydroponic Nutrient Solution}

A nutrient solution was prepared following the formula of modified half-strength Hoagland solution. The nutrient solution contained $\mathrm{NO}_{3}{ }^{-}-\mathrm{N} 42 \mathrm{mg} \mathrm{L}{ }^{-1}, \mathrm{SO}_{4}{ }^{2-}-\mathrm{S} 32 \mathrm{mg} \mathrm{L}{ }^{-1}$, $\mathrm{H}_{2} \mathrm{PO}_{4}^{-}-\mathrm{P} 31 \mathrm{mg} \mathrm{L}^{-1}, \mathrm{~K}^{+} 78 \mathrm{mg} \mathrm{L}{ }^{-1}, \mathrm{Mg}^{2+} 24 \mathrm{mg} \mathrm{L}^{-1}, \mathrm{Ca}^{2+} 40$ $\mathrm{mg} \mathrm{L}{ }^{-1}, \mathrm{Fe}^{2+} 2800 \mu \mathrm{g} \mathrm{L}^{-1}, \mathrm{Cu}^{2+} 20 \mu \mathrm{g} \mathrm{L}^{-1}, \mathrm{Zn}^{2+} 50 \mu \mathrm{g} \mathrm{L}^{-1}$, $\mathrm{Mn}^{2+} 500 \mu \mathrm{g} \mathrm{L}^{-1}, \mathrm{~B}(\mathrm{OH})_{4}^{-}-\mathrm{B} 500 \mu \mathrm{g} \mathrm{L}^{-1}$, and $\mathrm{MoO}_{4}{ }^{2-}-\mathrm{Mo} 10$ $\mu \mathrm{g} \mathrm{L}^{-1}$. Analytical grade chemicals were dissolved in underground water to make the desired elemental concentrations of the nutrient solution.

The nutrient solution had originally $\mathrm{pH}$ of 8.2 . It was further adjusted to $\mathrm{pH} 5.6 \pm 0.2$ with different inorganic acids. According to the acids used for $\mathrm{pH}$ adjustment, five treatments of nutrient solutions were generated: 1) Control $80 \mathrm{~L}$ of the original nutrient solution without any $\mathrm{pH}$ adjustments; 2) $\mathrm{HNO}_{3}-80 \mathrm{~L}$ of the original nutrient solution were adjusted to $\mathrm{pH} 5.6 \pm 0.2$ using $1 \mathrm{M} \mathrm{HNO}_{3} ; 3$ ) $\mathrm{H}_{2} \mathrm{SO}_{4}-80 \mathrm{~L}$ of the original nutrient solution were adjusted to $\mathrm{pH} 5.6 \pm 0.2$ using $1 \mathrm{M} \mathrm{H}_{2} \mathrm{SO}_{4}$; 4) $\mathrm{H}_{3} \mathrm{PO}_{4}-80 \mathrm{~L}$ of the original nutrient solution were adjusted to $\mathrm{pH} 5.6 \pm 0.2$ using $1 \mathrm{M} \mathrm{H}_{3} \mathrm{PO}_{4}$; and 5) Mixed Acids $-80 \mathrm{~L}$ of the original nutrient solution were adjusted to $\mathrm{pH} 5.6 \pm 0.2$ using mixed $3: 1: 1(\mathrm{v} / \mathrm{v} / \mathrm{v}) 1 \mathrm{M} \mathrm{HNO}_{3}: 1 \mathrm{M} \mathrm{H}_{2} \mathrm{SO}_{4}: 1 \mathrm{M} \mathrm{H}_{3} \mathrm{PO}_{4}$.

\section{Hydroponic Growth of Water Spinach}

Water spinach (Ipomoea aquatica Forsk cv. bamboo leaf) seeds were procured from a local seed company in Beijing, China. Prior to germination, the seeds were treated with $0.5 \%(\mathrm{w} / \mathrm{w}) \mathrm{K}_{2} \mathrm{MnO}_{4}$ solution for $0.5 \mathrm{~h}$ to destroy any pathogens, rinsed triply with deionized water and soaked in saturated $\mathrm{CaSO}_{4}$ solution at $30^{\circ} \mathrm{C}$ for $4 \mathrm{~h}$. The pre-treated seeds were then germinated by placing them on a moist filter paper in darkness at $25^{\circ} \mathrm{C}$ for $24 \mathrm{~h}$. The germinated seeds were then transferred to identically ten trays of sponge cubes, irrigated with no $\mathrm{pH}$-adjustment nutrient solutions, and grew in an incubation chamber for 14 days prior to transplanting.

Five hydroponic growth channels were prepared, each containing one of the five $\mathrm{pH}$-adjustment nutrient solutions, respectively. The growth channels were $500 \mathrm{~cm}$ (length) $\times$ $50 \mathrm{~cm}$ (width) $\times 12 \mathrm{~cm}$ (height) NFT-PVC (nutrient film technology-polyvinyl chloride) gullies acquired from Beijing vegetable research center. Each growth channel was covered with five polyfoam boards $(100 \mathrm{~cm} \times 50 \mathrm{~cm})$ each carrying 49 plantation holes ( $3 \mathrm{~cm}$ in diameter). The growth channels were located in a solar greenhouse at the National Experimental Station for Precision Agriculture, Beijing, China. A 60-L PVC tank was stationed underneath each of the growth channels to contain the nutrient solutions. A hydraulic pump (Model 4500A, Haili Pump Company, Guangdong, China) was installed to each tank to circulate nutrient solution between the tank and the channel. The 14-d water spinach seedlings corresponding to the nutrient solution treatments were transplanted to the growth channels in the polyfoam boards in rows at $7.5 \mathrm{~cm}$ in-row spacing and $15 \mathrm{~cm}$ between-row spacing. In each polyfoam board 16 seedlings were planted. A total of 80 seedlings were transplanted in each growth channel. The recirculating pump was operated for continuously 15 min every hour. The nutrient solutions in the hydroponic systems were refilled to their original volumes ( $\sim 80 \mathrm{~L}$ after recirculation) in the tanks every three days during the experiments. The water spinaches were grown for 25 days before harvesting.

\section{Analytical Measurements}

Air temperature in the greenhouse was recorded every 30 min using an automatic recording thermometer (model STR30, Senxte Company, Tianjin, China) during the hydroponic experiments. The $\mathrm{pH}$ of the nutrient solutions were monitored every $2 \mathrm{~d}$ at 10:00 am using a portable $\mathrm{pH}$ meter (model PHJ-90B, Beijing Hangtian Computer Co., Beijing, China). If a reading was greater than 6.5 , the inorganic acid corresponding to the treatment (except Control) was immediately added to bring the solution $\mathrm{pH}$ back to $5.6 \pm 0.2$. The volumes of the acids added were recorded. No efforts were made to regulate the $\mathrm{pH}$ of the Control nutrient solution.

To examine the $\mathrm{pH}$ and nutrient dynamics of hydroponic solution as a function of plant growth (nutrient absorption), an intensive 3-d monitoring of the nutrient solution chemistry was carried out 21 days ( 3 weeks) after transplanting. Every 2 h from 9:00 am of the start day, a 40 $\mathrm{mL}$ sample was collected from each of the five treatment systems. The samples were immediately measured for $\mathrm{pH}$ using the portable $\mathrm{pH}$ meter and for electric conductivity 
(EC) using a conductivity meter (model DDS-307, Shanghai Precision and Scientific Instrument Inc., Shanghai, China). Aliquots of the samples were measured for $\mathrm{NO}_{3}{ }^{-}$ concentrations using an ion selective electrode (model $\mathrm{PNO}_{3}-1$, Shanghai Guangdian Device Factory, Shanghai, China). The samples were further measured for water soluble phosphate concentrations following the molybdenum blue method (Murphy and Riley, 1962). Concentrations of $\mathrm{SO}_{4}{ }^{2-}$ in interval of $4 \mathrm{~h}$ were determined using a spectrophotometer (model 752, Shanghai Spectrum Instruments, Shanghai, China) following the turbidimetric method (Chesnin and Yien, 1951).

After 25 days of hydroponic growth, the water spinach plants were harvested. Individual plants from each of the solution treatment systems were randomly selected, cut off the roots, and measured for plant height and fresh weight. Aliquots of the fresh shoots were dried at constant weight in an oven at $75^{\circ} \mathrm{C}$. The dry weight of the plants was recorded. The fresh shoots were further ground into slurries and analyzed for quality parameters. The contents of soluble sugar, vitamin $\mathrm{C}$, and crude proteins were determined following the 2, 6-dichloro-indophenol titration method, the anthrone ethyl acetate colorimetic method and the coomassie brilliant blue G250 dye binding method ( $\mathrm{Li}$, 2000), respectively. The $\mathrm{NO}_{3}{ }^{-}$content was measured following the salycilic acid method ( $\mathrm{Li}, 2000)$. The results are expressed on the fresh weight basis of plants.

\section{Statistical Analysis}

Analysis of variance (ANOVA) was conducted using the SPSS 19.0 statistical software to evaluate the effect of $\mathrm{pH}$ adjustment of nutrient solution on the yield and nutritional quality of water spinach. Sample comparisons by Duncan multiple range tests were used to predict the significance of effect differences between any two treatments. The level of significance was set at 0.05 .

\section{Results}

\section{Daily Courses of Air Temperature}

The 30-min air temperature profiles of the greenhouse were carried out is presented in Fig. 1. The temperature fluctuated between 22 and $38^{\circ} \mathrm{C}$, reflecting the diurnal shifting and weather variations. The daily fluctuation pattern raised the maximum temperature at 1:00 pm of the day and declined to the minimum value at 6:00 am. The daily minimum temperature also demonstrated a generally decreasing trend due to the seasonal changes during the experiments (from August to September). The average temperature was $26.4^{\circ} \mathrm{C}$ during the experimental period.

pH and Nutrient Dynamics of Hydroponic Solution

Fig. 2 illustrates the $\mathrm{pH}$ of the nutrient solutions with artificial regulation through inorganic acid addition during the 25-d hydroponic growth of water spinach. For the Control treatment without $\mathrm{pH}$ adjustments, the nutrient solution demonstrated a high $\mathrm{pH}$ value of approximately $8.2 \pm 0.2$, not optimal for plant growth. For other treatments, the $\mathrm{pH}$ of the nutrient solutions increased rapidly from the initial level of 5.5 to above 6.5 within 1-3 d during hydroponic growth. Addition of inorganic acids had to be exercised to bring the $\mathrm{pH}$ level back to 5.5. Over the 25-d course of hydroponic growth, 12 times of $\mathrm{pH}$ regulations were implemented to the $\mathrm{HNO}_{3}$ treatment and 8 times to the Mixed Acids treatment. For both the $\mathrm{H}_{2} \mathrm{SO}_{4}$ and $\mathrm{H}_{3} \mathrm{PO}_{4}$ treatments, only 4 times of acid addition were performed at the beginning of hydroponic growth. Table 1 lists the volumes of acids consumed to regulate the $\mathrm{pH}$ level of the nutrient solutions to the optimal range of 5.5-6.5. A total of $1,294 \mathrm{~mL}$ of $1 \mathrm{M} \mathrm{HNO}_{3}, 573 \mathrm{~mL}$ of $1 \mathrm{M} \mathrm{H}_{2} \mathrm{SO}_{4}, 880 \mathrm{~mL}$ of $1 \mathrm{M} \mathrm{H}_{3} \mathrm{PO}_{4}$, and $1,080 \mathrm{~mL}$ of the mixed acids $(648 \mathrm{~mL}$ $\mathrm{HNO}_{3}, 216 \mathrm{~mL} \mathrm{H}_{2} \mathrm{SO}_{4}$, and $216 \mathrm{~mL} \mathrm{H}_{3} \mathrm{PO}_{4}$ ) were used.

Changes in $\mathrm{pH}$ of the nutrient solutions as a function of hydroponic growth of water spinach were investigated by an intensive, every 2-h monitoring program over $70 \mathrm{~h}$. As shown in Fig. 3(a), all the treatments with the initial $\mathrm{pH}$ adjustments to $5.6 \pm 0.2$ (not Control) exhibited a similar trend of $\mathrm{pH}$ shifts within the first $4 \mathrm{~h}$ following acid addition: the solution $\mathrm{pH}$ increased slowly yet steadily as time progressed. Afterwards, the solution $\mathrm{pH}$ of the $\mathrm{H}_{2} \mathrm{SO}_{4}$ treatment decreased back to 5.5 in another $12 \mathrm{~h}$, rose to 6.1 in the following $6 \mathrm{~h}$, and then decreased gradually to 3.7 at the end of the 3-d monitoring. In comparison, the solution $\mathrm{pH}$ of the $\mathrm{H}_{3} \mathrm{PO}_{4}$ treatment continued to increase to a peak value of 5.9 in $10 \mathrm{~h}$, and then decreased gradually to 3.8 over time. Both the $\mathrm{HNO}_{3}$ and Mixed Acids treatments, however, raised their solution $\mathrm{pH}$ to 6.5 in $20 \mathrm{~h}$ and maintained above 6.5 (but below 7.0) to the $64 \mathrm{~h}$. Later the $\mathrm{HNO}_{3}$ treatment elevated its solution $\mathrm{pH}$ continuously to 7.2 at the end of the 72-h monitoring, while the Mixed Acids treatment decreased its solution $\mathrm{pH}$ to 6.0.

Fig. 3(b) presents the EC dynamics of the differently treated nutrient solutions as a function of hydroponic growth of water spinach. The $\mathrm{pH}$ adjustments did influence the EC of the nutrient solutions; with the $\mathrm{H}_{2} \mathrm{SO}_{4}$ treatment had the highest EC while the Control had the lowest EC among the five treatments. Nevertheless, all the nutrient solutions maintained the EC in a range of $1200-1400 \mu \mathrm{S} \mathrm{cm}^{-1}$. The EC fluctuated in the first $66 \mathrm{~h}$. And, then it demonstrated a slight yet clear decreasing trend in the final $4 \mathrm{~h}$ of monitoring.

The concentration profiles of $\mathrm{NO}_{3}{ }^{-}, \mathrm{SO}_{4}{ }^{2-}$, and water soluble phosphate in the nutrient solutions over the 3-d intensive monitoring course are displayed in Fig. 4. In general, the concentrations of $\mathrm{NO}_{3}^{-}$and water soluble phosphate demonstrated a gradually decreasing trend, while the concentration of $\mathrm{SO}_{4}{ }^{2-}$ remained relatively constant. For the $\mathrm{HNO}_{3}$, Mixed Acids, and Control treatments, the $\mathrm{NO}_{3}$ concentration decreased from 618.89 to $71.19 \mathrm{mg} \mathrm{L}^{-1}$, from 191.13 to $4.50 \mathrm{mg} \mathrm{L}^{-1}$, and from 139.5 to $0.58 \mathrm{mg} \mathrm{L}^{-1}$, 
Table 1: Inorganic acids consumed to regulate the $\mathrm{pH}$ of the hydroponic nutrient solutions

\begin{tabular}{lcccc}
\hline Treatment & $1 \mathrm{M} \mathrm{HNO}_{3}(\mathrm{~mL})$ & $1 \mathrm{M} \mathrm{H}_{3} \mathrm{PO}_{4}(\mathrm{~mL})$ & $1 \mathrm{M} \mathrm{H}_{2} \mathrm{SO}_{4}(\mathrm{~mL})$ & 0 \\
\hline Control & 0 & 0 & 0 & Total $(\mathrm{mL})$ \\
$\mathrm{HNO}_{3}$ & 1294 & 0 & 0 & 0 \\
$\mathrm{H}_{2} \mathrm{SO}_{4}$ & 0 & 0 & 573 & 573 \\
$\mathrm{H}_{3} \mathrm{PO}_{4}$ & 0 & 880 & 0 & 880 \\
Mixed Acids & 648 & 216 & 216 & 1080 \\
\hline
\end{tabular}

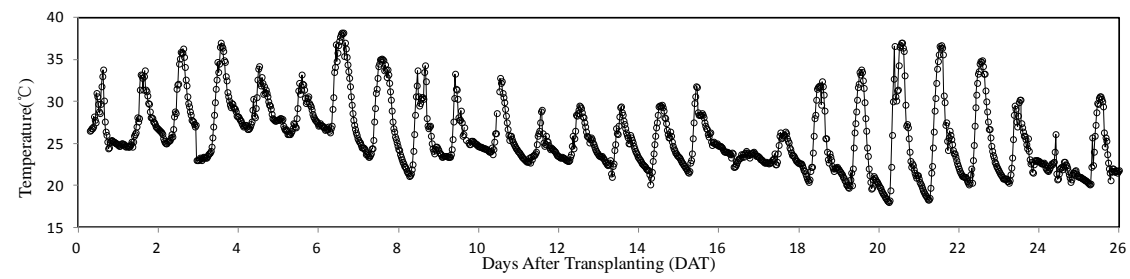

Fig. 1: The 30-min air temperature profile of the hydroponic environment

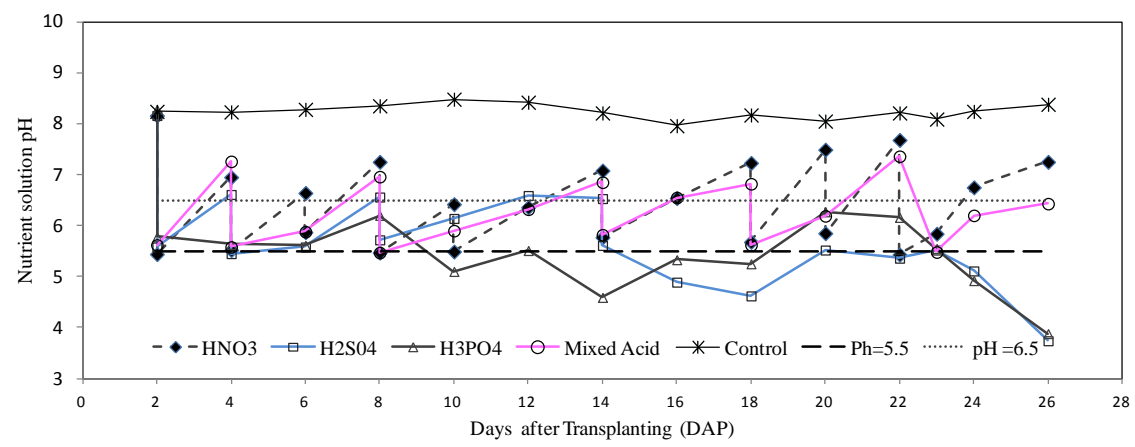

Fig. 2: The $\mathrm{pH}$ of nutrient solutions regulated with inorganic acid adjustments every two days during the hydroponic growth of water spinach

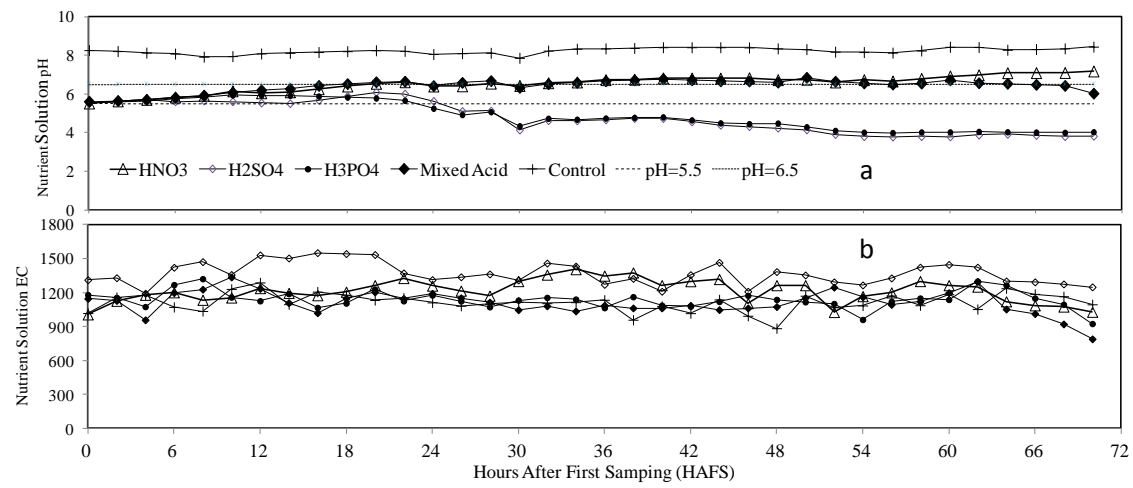

Fig. 3: The 3-d dynamics of nutrient solution $\mathrm{pH}$ (a) and electrical conductivity (b) as influenced by hydroponic growth of water spinach

respectively. The nutrient solutions of the $\mathrm{H}_{2} \mathrm{SO}_{4}$ and $\mathrm{H}_{3} \mathrm{PO}_{4}$ treatments contained rather low concentrations of $\mathrm{NO}_{3}^{-}(<10$ $\mathrm{mg} \mathrm{L}^{-1}$ ) after 21 days of hydroponic growth, approaching $0.5 \mathrm{mg} \mathrm{L}^{-1}$ at the end of the 3-d monitoring (Fig. 4a). The concentrations of water soluble phosphate in Control, $\mathrm{HNO}_{3}$, and $\mathrm{H}_{2} \mathrm{SO}_{4}$ treatments remained relatively constant around 51, 22, and $48 \mathrm{mg} \mathrm{L}^{-1}$, respectively. For the $\mathrm{H}_{3} \mathrm{PO}_{4}$ treatment, the nutrient solution decreased its water soluble phosphate concentration from $170 \mathrm{mg} \mathrm{L}^{-1}$ to $120 \mathrm{mg} \mathrm{L}^{-1}$ in the first $56 \mathrm{~h}$ and then elevated it back to approximately 150 $\mathrm{mg} \mathrm{L}^{-1}$. For the Mixed Acids treatment, the water soluble phosphate concentration decreased from $82.2 \mathrm{mg} \mathrm{L}^{-1}$ to 26.7 $\mathrm{mg} \mathrm{L}^{-1}$ over the 3-d monitoring course (Fig. 4b). In the same course the average $\mathrm{SO}_{4}{ }^{2-}$ concentrations of the Control, $\mathrm{HNO}_{3}, \mathrm{H}_{2} \mathrm{SO}_{4}, \mathrm{H}_{3} \mathrm{PO}_{4}$, Mixed Acids treatments maintained relatively constant at $103.7,117.0,313.1,99.8$ and $201.7 \mathrm{mg}$ 


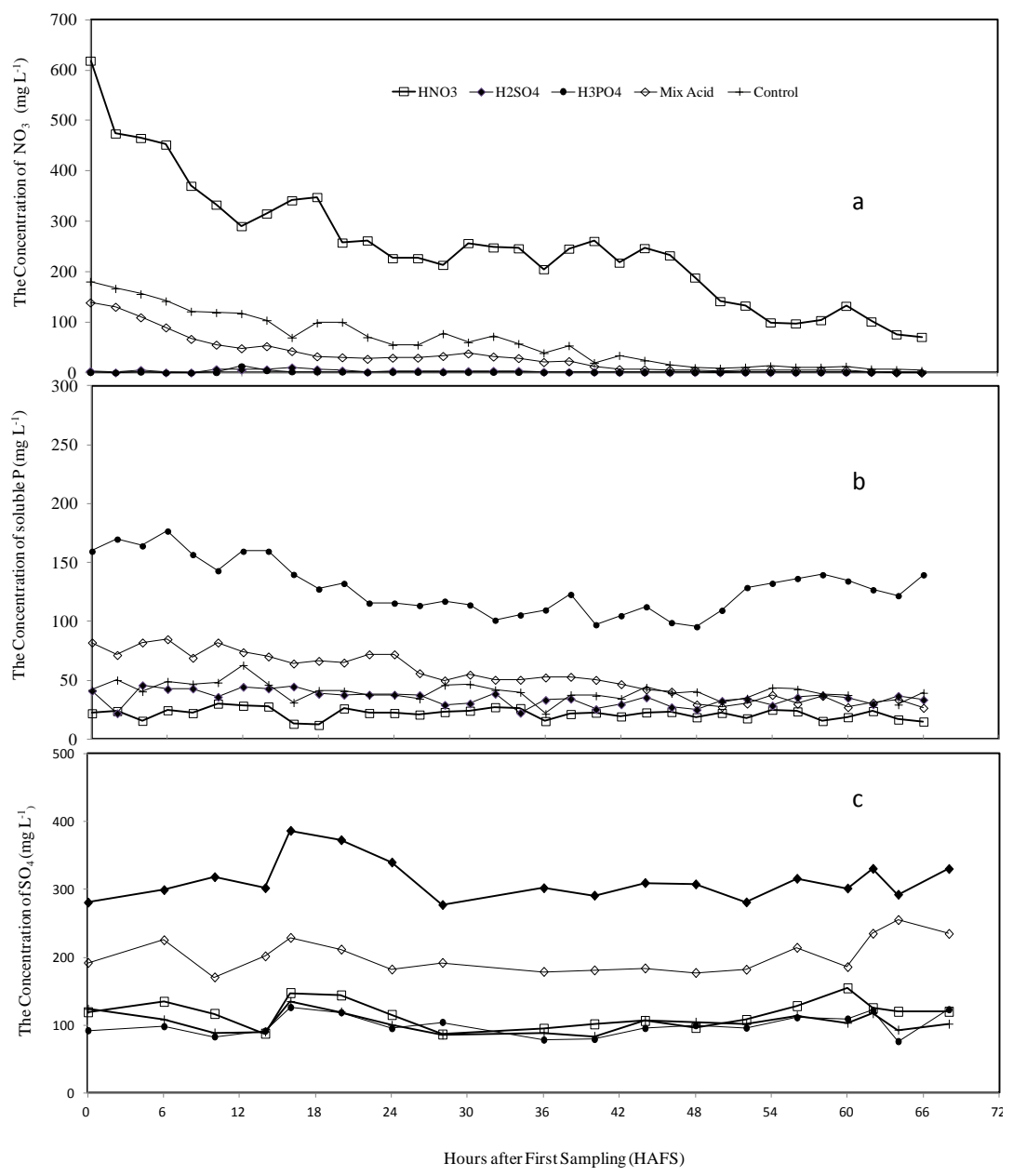

Fig. 4: Changes of concentrations of nitrate $\left(\mathrm{NO}_{3}^{-}, \mathrm{a}\right)$, water soluble phosphate (Soluble $\left.\mathrm{P}, \mathrm{b}\right)$, and sulfate $\left(\mathrm{SO}_{4}{ }^{2-}, \mathrm{c}\right)$ in nutrient solution as affected by hydroponic growth of water spinach

$\mathrm{L}^{-1}$, respectively (Fig. $4 \mathrm{c}$ ).

\section{Yield and Nutritional Quality of Hydroponic Water Spinach}

The above-root plant height, fresh weight (FW), dry weight (DW), and FW/DW ratio of water spinach hydroponically grown in the five solution treatments are given in Table 2. Relative to the Control, the $\mathrm{HNO}_{3}$ and Mixed Acids treatments showed significantly higher plant height, FW, and DW of water spinach, but not in the DW/FW ratio. The $\mathrm{H}_{2} \mathrm{SO}_{4}$ and $\mathrm{H}_{3} \mathrm{PO}_{4}$ treatments yielded water spinach similar to or significantly lower plant height, FW and DW yet significantly higher in DW/FW ratios than Control. Among the five treatments, the Mixed Acids treatment followed by the $\mathrm{HNO}_{3}$ treatment had the highest plant height, $\mathrm{FW}$, and DW of water spinach.

The contents of vitamin $\mathrm{C}$, soluble sugar, crude protein, and $\mathrm{NO}_{3}^{-}$in the shoots of water spinach are listed in Table 3. Among the five treatments, the Mixed Acids showed the highest contents of vitamin $\mathrm{C}\left(225.3 \mathrm{mg} \mathrm{kg}^{-1}\right)$, soluble sugar $\left(9.32 \mathrm{~g} \mathrm{~kg}^{-1}\right)$, and crude protein $\left(2.75 \mathrm{mg} \mathrm{kg}^{-1}\right)$. The highest $\mathrm{NO}_{3}^{-}$content was observed in the $\mathrm{HNO}_{3}$ treatment. Compared with the Control, both $\mathrm{HNO}_{3}$ and Mixed Acids treatments yielded water spinach with significantly higher vitamin $\mathrm{C}$, soluble sugar and crude protein contents. Nevertheless, water spinach from in the both treatments also contained significantly higher contents of $\mathrm{NO}_{3}^{-}$(Table 3).

\section{Discussion}

The $\mathrm{pH}$ value of nutrient solution is an important factor affecting the nutrient availability and plant uptake in soilless culture (Wan et al., 1994; Roosta, 2011). The optimal pH of nutrient solution for hydroponic plant growth is in the range of 5.5-6.5. The $\mathrm{pH}$ of the nutrient solution, however, changes with the course of hydroponic growth primarily as a result of plant selective absorption of nutrient ions. It is nearly impossible to maintain the nutrient solution $\mathrm{pH}$ in the 
Table 2: Plant height and biomass yield of hydroponically grown water spinach. Data are represented as mean \pm standard deviation of five replicate measurements

\begin{tabular}{lllll}
\hline Treatment & Plant height $(\mathrm{mm})$ & Fresh weight $(\mathrm{g})$ & Dry weight $(\mathrm{g})$ & Dry weight/fresh weight $(\mathrm{g} / \mathrm{g})$ \\
\hline Control & $41.28 \pm 2.46 \mathrm{~b}^{*}$ & $20.6 \pm 3.98 \mathrm{a}^{*}$ & $1.60 \pm 0.33 \mathrm{a}^{*}$ & $0.08 \pm 0.021 \mathrm{ab} *$ \\
$\mathrm{HNO}_{3}$ & $57.31 \pm 5.06 \mathrm{c}$ & $28.18 \pm 2.07 \mathrm{~b}$ & $1.98 \pm 0.11 \mathrm{ab}$ & $0.07 \pm 0.007 \mathrm{~b}$ \\
$\mathrm{H}_{2} \mathrm{SO}_{4}$ & $39.77 \pm 2.64 \mathrm{~b}$ & $16.76 \pm 1.47 \mathrm{a}$ & $1.65 \pm 0.23 \mathrm{a}$ & $0.10 \pm 0.006 \mathrm{a}$ \\
$\mathrm{H}_{3} \mathrm{PO}_{4}$ & $27.72 \pm 4.16 \mathrm{a}$ & $19.59 \pm 2.23 \mathrm{a}$ & $1.79 \pm 0.13 \mathrm{a}$ & $0.10 \pm 0.005 \mathrm{a}$ \\
Mixed Acids & $68.83 \pm 2.48 \mathrm{~d}$ & $36.51 \pm 3.12 \mathrm{c}$ & $2.54 \pm 0.18 \mathrm{~b}$ & $0.07 \pm 0.007 \mathrm{~b}$ \\
\hline
\end{tabular}

*Letters after the numbers in the same column for the same analytical parameter indicate the significance of differences between two treatments by the Duncan test $(n=5)$ at $\alpha=0.05$. Different letters suggest the differences are significant

Table 3: Nutritional quality of water spinach growing in differently treated hydroponic nutrient solutions. Data are represented as mean \pm standard deviation of five replicate measurements

\begin{tabular}{lllll}
\hline Treatment & Vitamin C mg kg & NW & Nitrate $\mathrm{mg} \mathrm{kg}^{-1} \mathrm{FW}$ & Soluble sugar mg kg \\
\hline Control $\mathrm{FW}$ & Crude Protein $\mathrm{mg} \mathrm{kg}^{-1} \mathrm{FW}$ \\
$\mathrm{HNO}_{3}$ & $112.04 \pm 17.60 \mathrm{~b}^{*}$ & $1188.45 \pm 44.53 \mathrm{~b}^{*}$ & $8.70 \pm 0.92 \mathrm{bc}^{*}$ & $1.75 \pm 0.30 \mathrm{a}^{*}$ \\
$\mathrm{H}_{2} \mathrm{SO}_{4}$ & $173.28 \pm 20.63 \mathrm{c}$ & $2236.95 \pm 188.25 \mathrm{c}$ & $6.59 \pm 0.72 \mathrm{a}$ & $2.03 \pm 0.03 \mathrm{bc}$ \\
$\mathrm{H}_{3} \mathrm{PO}_{4}$ & $91.20 \pm 7.19 \mathrm{ab}$ & $779.43 \pm 169.74 \mathrm{a}$ & $7.74 \pm 1.31 \mathrm{abc}$ & $1.84 \pm 0.51 \mathrm{a}$ \\
Mixed Acids & $57.79 \pm 6.36 \mathrm{a}$ & $674.83 \pm 39.54 \mathrm{a}$ & $7.13 \pm 0.82 \mathrm{ab}$ & $1.62 \pm 0.83 \mathrm{a}$ \\
\hline FW: fresh weight & $225.30 \pm 16.31 \mathrm{~d}$ & $1637.62 \pm 267.06 \mathrm{bc}$ & $9.32 \pm 0.59 \mathrm{c}^{*}$ & $2.75 \pm 0.28 \mathrm{c}$ \\
*Letters after the numbers in the same column for the same analytical parameter indicate the significance of differences between two treatments by the \\
Duncan test $(\mathrm{n}=3$ ) at $\alpha=0.05$. Different letters suggest the differences are significant
\end{tabular}

optimal range during hydroponic production without external addition of $\mathrm{pH}$ buffers. In the present study, inorganic acids were used to adjust the nutrient solution $\mathrm{pH}$ from the initially 8.2 and later $>6.5$ values to 5.5 (Fig. 2). For the $\mathrm{HNO}_{3}$ treatment in which $\mathrm{HNO}_{3}$ was used as the $\mathrm{pH}$ adjustment, the $\mathrm{pH}$ of the nutrient solution increased from 5.5 to 6.5 within $22 \mathrm{~h}$ following the acid addition, similar to the results reported by Lykas et al. (2006) and Savvas et al. (2006). The increase in $\mathrm{pH}$ of nutrient solution is mainly related to the release of $\mathrm{HCO}_{3}^{-}$and $\mathrm{OH}^{-}$from plant roots to maintain the charge neutrality in absorbing $\mathrm{NO}_{3}{ }^{-}$and other anionic nutrients from nutrient solution (Keltjens and Nijenstein, 1987). The $\mathrm{NO}_{3}{ }^{-}$added to the nutrient solution in the form of $\mathrm{HNO}_{3}$ was absorbed by water spinach, leading to a dramatic rise in $\mathrm{pH}$ of the nutrient solution (Fig. 2). When mixed acids were used, a relatively stable $\mathrm{pH}$ (5.56.5) was achieved during the 3 days of monitoring (Mixed Acids in Fig. 3a), suggesting an equilibrium state of nutrient components in the solution. When single $\mathrm{H}_{3} \mathrm{PO}_{4}$ or $\mathrm{H}_{2} \mathrm{SO}_{4}$ was used as the $\mathrm{pH}$ adjustment, the nutrient solution $\mathrm{pH}$ decreased gradually from 5.5 to 4.2 in 3 days $\left(\mathrm{H}_{2} \mathrm{SO}_{4}\right.$ and $\mathrm{H}_{3} \mathrm{PO}_{4}$ in Fig. 3a). Likely, the leaf vegetable water spinach needed and actually absorbed $\mathrm{SO}_{4}{ }^{2-}$ or water soluble phosphate much less than $\mathrm{NO}_{3}^{-}$and therefore, the corresponding $\mathrm{HCO}_{3}^{-}$and $\mathrm{OH}^{-}$released from plant roots could not offset the $\mathrm{H}^{+}$released from absorption of cationic nutrients (e.g, $\mathrm{Ca}^{2+}, \mathrm{Mg}^{2+}$ and $\mathrm{K}^{+}$), resulting in the $\mathrm{pH}$ decreases. The results indicate that single $\mathrm{H}_{3} \mathrm{PO}_{4}$ or $\mathrm{H}_{2} \mathrm{SO}_{4}$ is not suitable for buffering the $\mathrm{pH}$ of hydroponic nutrient solution; otherwise a harmful low $\mathrm{pH}$ environment may be rapidly formed (Islam et al., 1980; Spinu et al., 1997).

The level of $\mathrm{pH}$ greatly influences the speciation and nutrient availability such as $\mathrm{P}, \mathrm{Fe}, \mathrm{Mg}, \mathrm{Cu}$ and $\mathrm{Mn}$ in hydroponic solution. The EC of a nutrient solution is closely related to the sum concentration of dissolved salts in the solution. In the present study, no significant differences in EC were observed among the four nutrient solution treatments other than $\mathrm{H}_{2} \mathrm{SO}_{4}$, which demonstrated slightly yet consistently higher EC values (Fig. 3). In contrast, the concentrations of $\mathrm{NO}_{3}{ }^{-}$, water soluble phosphate, and $\mathrm{SO}_{4}{ }^{2-}$ in the nutrient solutions were significantly different, respectively, among the five treatments (Fig. 4). The decreased concentrations of $\mathrm{NO}_{3}{ }^{-}$over time in the $\mathrm{HNO}_{3}$, Mixed Acids, and Control treatments (Fig. 4a) were attributed to the strong uptake of $\mathrm{NO}_{3}^{-}-\mathrm{N}$ by water spinach. The differences of $\mathrm{NO}_{3}{ }^{-}$concentration between $\mathrm{HNO}_{3}$ and Mixed Acids treatments were chiefly caused by the different amounts of $\mathrm{HNO}_{3}$ added to the hydroponic systems for $\mathrm{pH}$ regulation (Table 1). At the same monitoring points, the $\mathrm{NO}_{3}{ }^{-}$concentration of Control treatment was clearly higher than that of the Mixed Acids treatment. It might be attributed to the inhibition of plant uptake of $\mathrm{NO}_{3}^{-}$from nutrient solution by a high $\mathrm{pH}$ environment. Kim et al. (2005) reported a similar observation that the $\mathrm{NO}_{3}{ }^{-}$uptake by hydroponic rose was restricted by the high $\mathrm{pH}$ level $(\mathrm{pH}=8)$ of the nutrient solution. In general, leaf crops take much less $\mathrm{P}$ and $\mathrm{S}$ than $\mathrm{N}$ to grow healthy (Brady and Weil, 2007). As a result, the nutrient solutions in the $\mathrm{H}_{3} \mathrm{PO}_{4}$ and $\mathrm{H}_{2} \mathrm{SO}_{4}$ treatments maintained relatively high concentrations of water soluble phosphate and $\mathrm{SO}_{4}^{2-}$, respectively (Fig. 4). Over-supply of water soluble phosphate and $\mathrm{SO}_{4}{ }^{2-}$ may occur, respectively, if $\mathrm{H}_{3} \mathrm{PO}_{4}$ and $\mathrm{H}_{2} \mathrm{SO}_{4}$ are used to regulate the $\mathrm{pH}$ of hydroponic nutrient solution.

Numerous studies have indicated that the growth of many plants is inhibited in soil and soilless conditions with a high pH level (Bertoni et al., 1992; Zribi and Gharsalli, 2002; Roosta, 2011; Roosta and Rezaei, 2014). It is critical to maintain the $\mathrm{pH}$ of the nutrient solution in an appropriate 
range for best hydroponic production (Voogt and Sonneveld, 2009). In the present study, the fresh weight and dry weight yields of water spinach grown in the $\mathrm{H}_{2} \mathrm{SO}_{4}, \mathrm{H}_{3} \mathrm{PO}_{4}$ and Control treatments were not significantly different (Table 2), suggesting that single $\mathrm{H}_{2} \mathrm{SO}_{4}$ or $\mathrm{H}_{3} \mathrm{PO}_{4}$ used as a $\mathrm{pH}$ adjustment of nutrient solution did not promote hydroponic growth of water spinach. A possible reason was that the nutrient solutions shifted to a strongly acidic condition (e.g., $\mathrm{pH}<4.5$, Fig. 2) as a result of the corresponding nutrient uptake by plants. Schubert et al. (1990) reported that nutrient uptake of beans was restricted at low $\mathrm{pH}$ level ( $\mathrm{pH}=4.0)$ of growth medium. Yan et al. (1992) observed poor growth of corn and broad bean at low growth medium $\mathrm{pH}$ (e.g., <4.0). The authors believed that a low $\mathrm{pH}$ environment inhibited proton $\left(\mathrm{H}^{+}\right)$release from plant roots and in turn, decreased the cytoplasmic $\mathrm{pH}$. Compared with Control, the $\mathrm{HNO}_{3}$ and Mixed Acids treatments significantly enhanced the growth of water spinach (Table 2). The highest plant height and fresh/dry weights of water spinach were achieved in the Mixed Acids treatment (Table 2). Mostly, the $\mathrm{pH}$ of the nutrient solution in this treatment was in the optimal range of 5.5-6.5 (Fig. 3). Another possible reason was the relatively balanced presence of $\mathrm{NO}_{3}{ }^{-}, \mathrm{SO}_{4}{ }^{2-}$, and water soluble phosphate in the nutrient solution from the mixed acid addition (Fig. 4). In comparison, $\mathrm{HNO}_{3}$ only did not work as effectively as the mixed acids in regulating the solution $\mathrm{pH}$, as indicated by the further shifting of $\mathrm{pH}$ away from the 6.5, $22 \mathrm{~h}$ after the $\mathrm{pH}$ adjustment (Fig. 3).

The vitamin $\mathrm{C}$ contents of water spinach showed significant differences among the five nutrient solution treatments, suggesting that the $\mathrm{pH}$ adjustments influenced the nutritional quality of hydroponic water spinach. The $\mathrm{NO}_{3}{ }^{-}$content of water spinach shoot was positively related to the amount of $\mathrm{HNO}_{3}$ added to the nutrient solutions (Table 3). Similar results were reported for hydroponicallygrown spinach, cabbage and lettuce (Wang and Li, 2004; Liu et al., 2014). However, for all the five treatments, the $\mathrm{NO}_{3}{ }^{-}$contents of water spinach did not exceed the maximum limit of $3,000 \mathrm{mg} \mathrm{kg}^{-1}$ for leaf vegetables (Shen et al., 1982). The sugar content of water spinach from the Mixed Acids treatment, though not significantly higher than the Control, was the highest among the five treatments (Table 3). A similar phenomenon was observed for the crude protein content of water spinach, indicating that the Mixed Acids treatment also facilitated accumulation of protein in hydroponic plants.

\section{Conclusion}

The $\mathrm{pH}$ of nutrient solution influenced the growth and nutritional quality of hydroponic crops. When single $\mathrm{H}_{2} \mathrm{SO}_{4}$ or $\mathrm{H}_{3} \mathrm{PO}_{4}$ was used to regulate the solution $\mathrm{pH}$ to the optimal range of 5.5-6.5, the hydroponic growth of water spinach was significantly inhibited. The inorganic acid $\mathrm{HNO}_{3}$ as a $\mathrm{pH}$ adjustment facilitated the growth of water spinach, but also resulted in significant accumulation of
$\mathrm{NO}_{3}{ }^{-}$in plant shoots. The mixed acids of $1 \mathrm{M} \mathrm{HNO} 3, \mathrm{H}_{3} \mathrm{PO}_{4}$ and $\mathrm{H}_{2} \mathrm{SO}_{4}$ at 3:1:1 (v/v/v) worked the most effectively as a $\mathrm{pH}$ adjustment in enhancing hydroponic plant growth and nutritional quality. The mixed acids were able to maintain the $\mathrm{pH}$ of hydroponic nutrient solution in the optimal range and provide a relatively balanced nutrient environment. Mixed $\mathrm{HNO}_{3}, \mathrm{H}_{3} \mathrm{PO}_{4}$ and $\mathrm{H}_{2} \mathrm{SO}_{4}$ is recommended to regulate the $\mathrm{pH}$ of hydroponic solution. Further research is needed to identify best proportion compositions of $\mathrm{HNO}_{3}$, $\mathrm{H}_{3} \mathrm{PO}_{4}$ and $\mathrm{H}_{2} \mathrm{SO}_{4}$ mixtures as a $\mathrm{pH}$ regulator in hydroponic production.

\section{Acknowledgements}

This work was financially supported by the National Natural Science Foundation of China (Project No. 51509005), the Natural Science Foundation of Beijing (Project No. 6144022 and 6142011), and the Youth Foundation of Beijing Academy of Agriculture and Forestry Sciences (Project No. QNJJ201421).

\section{References}

Aftab, M., M.A.U.L. Haq, J. Akhtar and E.A. Waraich, 2015. Salinity and boron tolerance in cotton (Gossypium hirsutum) varieties: A shortterm hydroponic study. Int. J. Agric. Biol., 17: 797-802

Bernstein, L. 1975. Effects of Salinity and Sodicity on Plant Growth. Phytopathology, 13: 295-312

Bertoni, G.M., A. Pissaloux, P. Morard and D.R. Sayag, 1992. Bicarbonate$\mathrm{pH}$ relationship with iron chlorosis in white lupine. J. Plant Nutr., 15: $1509-1518$

Brady, N.C. and R.R. Weil, 2007. The Nature and Properties of Soils, $14^{\text {th }}$ edition. Prentice Hall: Upper Saddle River, New Jersey, USA

Bugbee, B., 2004. Nutrient management in recirculating hydroponic culture. South Pacific Soilless Culture Conference-SPSCC, 648: 99-112

Caruso, G., G. Villari, G. Melchionna and S. Conti, 2011. Effects of cultural cycles and nutrient solutions on plant growth, yield and fruit quality of alpine strawberry (Fragaria vesca L.) grown in hydroponics. Sci. Hortic., 129: 479-485

Chesnin, L. and C.H. Yien, 1951. Turbidimetric determination of available sulfates. Soil. Sci. Soc. Amer. J., 15: 149-151

Domingues, D.S., H.W. Takahashi, C.A. Camara and S.L. Nixdorf, 2012. Automated system developed to control $\mathrm{pH}$ and concentration of nutrient solution evaluated in hydroponic lettuce production Comput. Electron. Arg., 84: 53-61

Giuffrida, F. and C. Leonardi, 2012. Nutrient solution concentration on pepper grown in a soilless closed system: yield, fruit quality, water and nutrient efficiency. Acta Scand., B-S. P., 62: 1-6

Gorbe, E., 2009. Study of nutrient solution management in soilless rose cultivation through the analysis of physiological parameters and nutrient absorption. PhD Dissertation. Polytechnic University of Valencia, Valencia, Spain

Gorbe, E. and A. Calatayud, 2010. Optimization of nutrition in soilless systems: a review. Adv. Bot. Res., 53: 193-245

Islam, A., D.G. Edwards and C.J. Asher, 1980. pH optima for crop growth. Plant Soil, 54: 339-357

Keltjens, W.G. and J.H. Nijenstein, 1987. Diurnal variations in uptake, transport and assimilation of $\mathrm{NO}_{3}{ }^{-}$and efflux of $\mathrm{OH}^{-}$in maize plants. J. Plant Nutr., 10: 887-900

Kim, H.J., Y.S. Cho, O.K. Kwon, M.W. Cho, J.B. Hwang, W.T. Jeon and S.D. Bae, 2005. Effect of hydroponic solution $\mathrm{pH}$ on the growth of greenhouse rose. Asian J. Plant Sci., 4: 17-22

Li, H., 2000. Principles and Techniques of Plant Physiological Biochemical Experiment. Higher Education Press, Beijing, China 
Liu, C.W., Y. Sung, B.C. Chen and H.Y. Lai, 2014. Effects of nitrogen fertilizers on the growth and nitrate content of lettuce (Lactuca sativa L.). Int. J. Environ. Res. Pub Heal., 11: 4427-4440

Lykas, C., N. Katsoulas, P. Giaglaras and C. Kittas, 2006. Electrical conductivity and $\mathrm{pH}$ prediction in a recirculated nutrient solution of a greenhouse soilless rose crop. J. Plant Nutr., 29: 1585-1599

Massa, D., L. Incrocci, R. Maggini, C. Bibbiani, G. Carmassi, F. Malorgio and A. Pardossi, 2011. Simulation of crop water and mineral relations in greenhouse soilless culture. Environ. Modell. Soft., 26 : $711-722$

Murphy, J. and H.P. Riley, 1962. A modified single solution method for the determination of phosphate in natural waters. Anal. Chim. Acta, 27: $31-36$

Prasad, M.N.V., M. Greger and T. Landberg, 2001. Acacia nilotica L. bark removes toxic elements from solution: corroboration from toxicity bioassay using Salix viminalis L. in hydroponic system. Int. J. Phytoremed., 3: 289-300

Rius-Ruiz, F.X., F.J. Andrade, J. Riu and F.X. Rius, 2014. Computeroperated analytical platform for the determination of nutrients in hydroponic systems. Food Chem., 147: 92-97

Roosta, H.R. and I. Rezaei, 2014. Effect of nutrient solution $\mathrm{pH}$ on the vegetative and reproductive growth and physiological characteristics of rose Cv. 'Grand Gala' in hydroponic system. J. Plant Nutr., 37: 2179-2194

Roosta, H.R., 2011. Interaction between water alkalinity and nutrient solution $\mathrm{pH}$ on the vegetative growth, chlorophyll fluorescence and leaf magnesium, iron, manganese, and zinc concentrations in lettuce. J. Plant Nutr., 34: 717-731

Savvas, D. and K. Adamidis, 1999. Automated management of nutrient solutions based on target electrical conductivity, $\mathrm{pH}$ and nutrient concentration ratios. J. Plant Nutr., 22: 1415-1432
Savvas, D., H.C. Passam, C. Olympios, E. Nasi, E. Moustaka, N. Mantzos and P. Barouchas, 2006. Effects of ammonium nitrogen on lettuce grown on pumice in a closed hydroponic system. HortScience, 41: 1667-1673

Schubert, S., E. Schubert and K. Mengel, 1990. Effect of low pH of the root medium on proton release, growth, and nutrient uptake of field beans (Vicia faba). Plant Soil, 124: 239-244

Shen, M.Z., B.J. Zha, H.R. Dong and J.G. Li, 1982. Studies on nitrate accumulation in vegetable crops. Acta Hortic. Sin., 9: 41-48

Spinu, V.C., R.W. Langhans and L.D. Albright, 1997. Electrochemical pH control in hydroponic systems. Model. Plant Growth, Environ. Cont. Farm Manage. in Prot. Cultivation, 456: 275-282

Voogt, W. and C. Sonneveld, 2009. The effects of Fe-chelate type and pH on substrate grown roses. Acta Hortic., 819: 411-417

Wan, W.Y., W. Cao and T.W. Tibbitts, 1994. Tuber initiation in hydroponically grown potatoes by alteration of solution $\mathrm{pH}$. HortScience, 29: 621-623

Wang, Z. and S. Li, 2004. Effects of nitrogen and phosphorus fertilization on plant growth and nitrate accumulation in vegetables. J. Plant Nutr., 27: 539-556

Webb, M.J., 1993. A multichannel $\mathrm{pH}$ controller for solution culture systems. Plant Soil, 155: 501-504

Wheeler, R.M., C.R. Hinkle, C.L. Mackowiak, J.C. Sager and W.M. Knott, 1990. Potato growth and yield using nutrient film technique (NFT). Amer. Potato J., 67: 177-187

Yan, F., S. Schubert and K. Mengel, 1992. Effect of low root medium pH on net proton release, root respiration, and root growth of corn ( $\mathrm{Zea}$ mays L.) and broad bean (Vicia faba L.) Plant Physiol., 99: 415-421

Zribi, K. and M. Gharsalli, 2002. Effect of bicarbonate on growth and iron nutrition of pea. J. Plant Nutr., 25: 2143-2149

(Received 20 December 2016; Accepted 27 February 2017) 